R. Tatiana Sánchez, H. Ivanna Tomasco, M. Mónica Díaz* and Rubén M. Barquez

\title{
Contribution to the knowledge of the rare "Famatina tuco-tuco", Ctenomys famosus Thomas 1920 (Rodentia: Ctenomyidae)
}

https://doi.org/10.1515/mammalia-2017-0131

Received October 5, 2017; accepted January 24, 2018; previously published online April 12, 2018

Abstract: Ctenomys famosus is one of the less known species of the genus, both in systematic and in phylogenetic aspects, as well as in its distribution and natural history. So far the only known specimens of this species are those from the type series, collected at the two localities mentioned in the original description, in La Rioja province, Argentina. We here provide new information about the species as well as some comments about the type locality, and add a new point to its known geographical distribution. In addition, the capture of topotypes allowed us to add unpublished information on molecular, morphological and cranial variables of the species. The phylogenetic analysis of mitochondrial gene cytochrome $b$ sequences positions $C$. famosus in the context of the existing phylogenetic hypotheses and proposals for the genus as belonging to the "mendocinus group". This information can serve as a basis for future research that favors clarifying the evolutionary panorama of the group at the regional level, as well as for completing the existing relationships within the complex of the Argentine species of the genus.

Keywords: cytochrome $b$; Famatina Chain; geographic distribution; La Rioja; type locality.

\footnotetext{
*Corresponding author: M. Mónica Díaz, Programa de Investigaciones de Biodiversidad Argentina (PIDBA), Facultad de Ciencias Naturales e Instituto Miguel Lillo, Universidad Nacional de Tucumán, Consejo Nacional de Investigaciones Científicas y Técnicas (CONICET), Miguel Lillo 251, Tucumán 4000, Argentina; and Fundación Miguel Lillo, Miguel Lillo 251, San Miguel de Tucumán, Tucumán 4000, Argentina, e-mail: mmonicadiaz@yahoo.com.ar R. Tatiana Sánchez and Rubén M. Barquez: Programa de Investigaciones de Biodiversidad Argentina (PIDBA), Facultad de Ciencias Naturales e Instituto Miguel Lillo, Universidad Nacional de Tucumán, Consejo Nacional de Investigaciones Científicas y Técnicas (CONICET), Miguel Lillo 251, Tucumán 4000, Argentina

H. Ivanna Tomasco: Laboratorio de Evolución, Facultad de Ciencias, Iguá 4225, Montevideo 11400, Montevideo, Uruguay (IHT)
}

\section{Introduction}

The current state of knowledge of the genus Ctenomys still contains several unanswered questions about systematics, biogeography and evolution of the species. The most recent compilation of the genus is that of Bidau (2015) who listed all recognized living species but stated that: "It is thus clear that the number of species will increase with the combination of much needed additional field collections and revisionary work".

The review by Bidau (2015) includes 69 species, of which 46 are distributed in Argentina. This significant increase of species compared with the 27 listed by Cabrera (1961) is remarkable, and it must be recognized that many of the forms indicated by Bidau were already described and retrieved from the synonymies and revalidated using the original names.

Ctenomys occupies a great diversity of habitats from sea level to an elevation of almost $5000 \mathrm{~m}$ and is distributed in Bolivia, Chile, Argentina, Paraguay, Uruguay and southwestern Brazil from the Peruvian highlands to Tierra del Fuego (Bidau 2015). All species of tuco-tucos have similar external morphology; the differentiation of the ctenomyids involved diverse adaptations to open habitats, especially those related to digging and life underground (Reig and Quintana 1992, Verzi 2002, Verzi and Olivares 2006, Bidau 2015). Among these morphological characteristics, a molar euhypsodonty, a crescent-shaped occlusal morphology adapted to an oblique mastication and subterranean specializations of the external body and limbs, skull and skeleton are included (Verzi 2002, Bidau 2015). Species of this genus have a body stout and cylindrical, a short tail and limbs and neck that are short and very thick; digits of the fore- and hindfeet have very strong claws and fringes of stiffened hairs that form a comb-like bristles; very small ears and small eyes but not as much reduced as in other subterranean mammals; incisors usually with bright orange enamel and kidney-shaped molars with the last one reduced in size (Bidau 2015).

Several species are virtually unknown with respect to various aspects of their natural history or ecology. 
Species are barely known from the original descriptions, which were based on a scarce number of specimens, generally consisting of the type, and occasionally with additional specimens. Also, their distributions are an enigma, are very fragmentary and basically are defined as being restricted to the type locality and peripheries.

As a result, and largely due to the scarcity of extensive studies and field collections, the actual distribution areas of the species remain ambiguous (Massarini et al. 1991); geographic boundaries are poorly defined for most species, probably due to the application of conservative criteria in terms of restricting distributions only to the peripheries of the type localities.

Some research efforts have been made over time on species of the genus Ctenomys such as those by Lessa and Cook (1998), Mascheretti et al. (2000), Slamovits et al. (2001), Castillo et al. (2005) and Parada et al. (2011), among others but, as established by Bidau (2015), the phylogenetic relationships within Ctenomys using molecular markers have only recently begun.

In this sense, Ctenomys famosus Thomas 1920 is not an exception but, on the contrary, it is one of the lesser known species of the group, due to the almost complete lack of information available on it. It is noteworthy that, since the collection by Emilio Budin in 1920 (Thomas 1920b), specimens of this species have not been obtained or cited and consequently remains restricted to the type locality and surroundings, in the Argentine province of La Rioja.

The description of the type is very brief, as are the descriptions of most species erected at that time, and as no other specimens have been obtained since 1920, there have been no additions or improvements in the knowledge of their morphological and cranial characteristics. In the first grouping of the species listed by Cabrera (1961), he treated Ctenomys famosus as a subspecies of Ctenomys fulvus Philippi 1860. Probably Cabrera decided to consider these as subspecies (Ctenomys coludo Thomas 1920, C. famosus, Ctenomys johannis Thomas 1921 and Ctenomys tulduco Thomas 1921) based on the closeness of the geographic distances of the four subspecific forms he erected; these four "subspecies" come from localities geographically close to each other, but the distribution of each subspecies is still basically restricted just to the type locality and surroundings. At present $C$. fulvus is considered to be restricted to Chile and has not been reported in Argentina; additionally, each of the four subspecies cited by Cabrera was considered as full species by Bidau (2015).

In the present study, we provide documented information for Ctenomys famosus, based on topotype specimens obtained by us, almost 100 years after the original collection. We also add accurate geographic information for the type locality, a new locality for the distribution of the species and an amended description, including skin and skull, based on the examination of topotypes, their comparison with specimens from the new locality, with the holotype and the paratype series deposited in the British Museum. Also, unpublished molecular information is offered, as well as taxonomic and biogeographical comments.

\section{Materials and methods}

In May 2015 and February 2016, we conducted field trips to two localities in search of more information concerning the rare "Famatina tuco-tuco", Ctenomys famosus, within the framework of a more comprehensive study on systematics and distribution of the mammals of La Rioja, Argentina. At both localities, we placed traps designed for the live capture of subterranean rodents, modified from the model by Baker and Williams (1972). The traps were placed early in the morning at the entrance of active caves and were checked every $2 \mathrm{~h}$. The specimens were measured following the protocols established by Díaz et al. (1998), prepared as skin, skull and skeleton and deposited in the Colección Mamíferos Lillo (CML), University of Tucumán, Argentina. Tissue samples were taken from the liver and were preserved in $96 \%$ ethyl-alcohol.

Additionally, for comparative purposes, the holotype and type series of Ctenomys famosus from the British Museum Natural History (BMNH), London, and specimens of Ctenomys rionegrensis Langguth and Abella 1970 from the type locality deposited at the collection of the EV (Laboratorio de Evolución, Facultad de Ciencias), Montevideo, Uruguay, were examined. We compared Ctenomys famosus with Ctenomys rionegrensis because this is the species with the more similar cytochrome $\mathrm{b}$ within the mendocinus group.

\section{Collecting localities (Figure 1)}

\section{1) Potrerillo, Sierras de Famatina, Famatina Depart- ment, La Rioja Province, Argentina}

This is probably the starting point for the fieldwork developed by Emilio Budin. The exact place where the type specimen of Ctenomys famosus was found is not clearly defined in the article but it was indicated as "Potrerillo, at about $2600 \mathrm{~m}$ ". As the village "Potrerillo" is at $1800 \mathrm{~m}$ elevation, we believe that Mr. Budin placed traps in the town and the surroundings, but also moved up to the western hills where he collected the type specimen, at $2600 \mathrm{~m}$, 


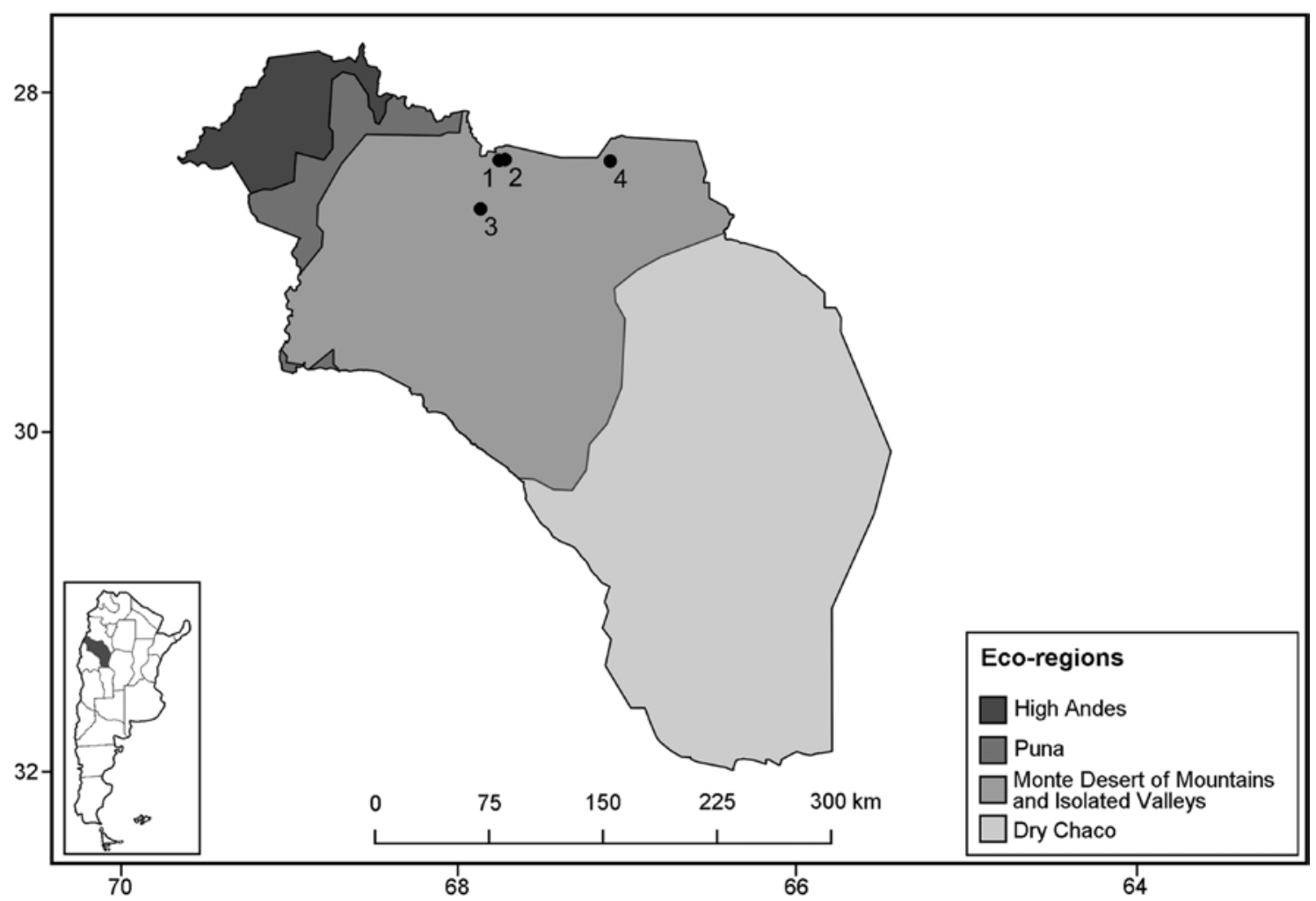

Figure 1: Locality records of Ctenomys famosus in La Rioja Province, Argentina: 1. Potrerillo, 3 km W, at the eastern slopes of Sierras de Famatina, $2600 \mathrm{~m}$; 2. Potrerillo 1600-1800 m; 3. La Invernada; 4. San Blas (see the Materials and methods section for details).

probably about $3 \mathrm{~km}$ west of the central point of the village of Potrerillo where that elevation is to be found. As a consequence, we believe that the actual locality for the type specimen should be refined with this criterion, including the correct elevation, as follows: "Potrerillo, $3 \mathrm{~km} \mathrm{~W}$, at the eastern slopes of Sierras de Famatina, 2600 m”.

In Potrerillo and its surroundings, Mr. Budin also captured three specimens used by Thomas to describe the species in 1920; other specimens were from La Invernada, in the northern half of the chain, about $35 \mathrm{~km}$ north of the mountain "Nevada de Famatina" and situated at an altitude of about $3800 \mathrm{~m}$ (Thomas 1920b).

At Potrerillo, in the town, we captured two topotype female specimens (CML 11028, 11029) and obtained tissue samples from them. The area corresponds to the ecoregion of Monte Desert of Mountains and Isolated Valleys (Figure 2A). It is characterized by two types of vegetation: high shrub steppes (1-3 m), which are the dominant type, and open woodlands of Prosopis. The dominant species are Zygophyllaceae, with Larrea, Bulnesia and Plectocarpha (Burkart et al.1999, Rundel et al. 2007). This formation generally occupies well-drained soils of inter-mountain and isolated valleys; while in the mountains slopes the shrubby vegetation is lower and scattered with emergent columnar cacti (Burkart et al. 1999) (Figure 2A).

\section{2) San Blas, 700 m east of town, San Blas de los Sauces Department, La Rioja Province, Argentina}

This locality is also found within the Monte Desert of Mountains and Isolated Valleys, but approximately $60 \mathrm{~km}$ east in a straight line from the type locality (Figure 2B). We collected two male specimens (CML 11030, 11031), identified as Ctenomys famosus based on molecular analysis and morphological comparison with the topotypes.

\section{Specimens examined (12)}

Ctenomys famosus, Argentina: La Rioja: Potrerillo, $3 \mathrm{~km}$ west, at the eastern slopes of Sierras de Famatina, $2600 \mathrm{~m}$ (28 $\left.23^{\prime} 59.12^{\prime \prime} \mathrm{S}, 67^{\circ} 44^{\prime} 10.94^{\prime \prime} \mathrm{W}\right), 1$ (BMNH 20.8.4.54 holotype, female); Potrerillo, Sierras de Famatina, 1600-1800 m (28 $23^{\prime} 46^{\prime \prime} \mathrm{S}, 67^{\circ} 42^{\prime} 5^{\prime \prime} \mathrm{W}$ ), 5 (3 BMNH 20.8.4.50 male, 20.8.4.51 male, 20.8.4.55 female; 2 CML 11028 topotype female, 11029 female); La Invernada, $3800 \mathrm{~m}$ (28 $21^{\prime} 12.34^{\prime \prime} \mathrm{S}$, $\left.67^{\circ} 50^{\prime} 47.62^{\prime \prime} \mathrm{W}\right), \quad 3 \quad$ (BMNH 20.8.4.49 male, 20.8.4.52 female, 20.8.4.53 female); San Blas, $700 \mathrm{~m}$ east of town, $1023 \mathrm{~m}\left(28^{\circ} 24^{\prime} 17.4^{\prime \prime} \mathrm{S}, 67^{\circ} 04^{\prime} 48.4^{\prime \prime} \mathrm{W}\right), 2$ (CML 11030 male, 11031 male). Ctenomys rionegrensis, Uruguay: Rio Negro: Balneario Las Cañas, boca del Arroyo, Las Cañas, $7 \mathrm{~km}$ to 


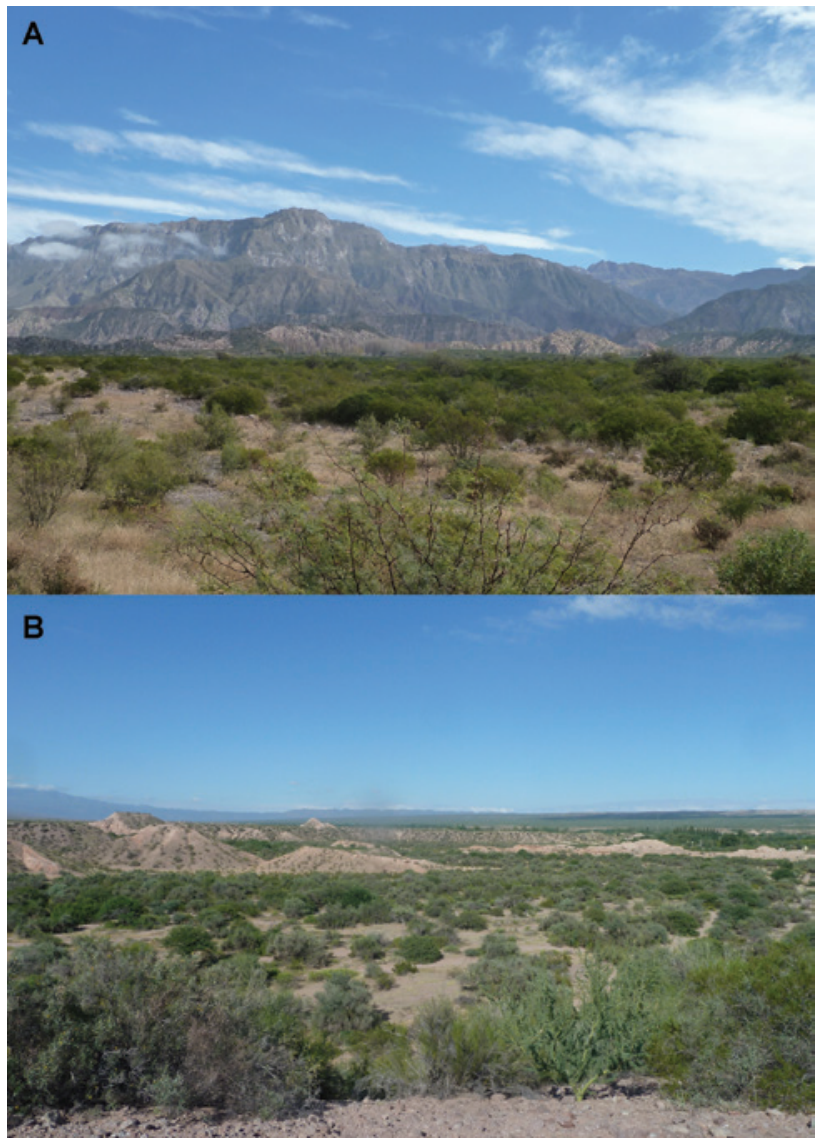

Figure 2: Pictures of habitats.

Potrerillo (type locality) (A) and San Blas (B), both areas correspond to the ecoregion of Monte Desert of Mountains and Isolated Valleys.

the southwest of Fray Bentos ( $33^{\circ} 11^{\prime} 20.4^{\prime \prime}$ S, 58 $\left.21^{\prime} 19.8^{\prime \prime W}\right), 3$ (EV 1996 female, 1997 female, 1998 female).

\section{Body measurements}

Body measurements (in millimeters) were taken as follows: total length (distance from the tip of the snout to the tip of the tail), tail length (distance between the point of insertion of the tail into the body and the last caudal vertebra), hindfoot length (distance from the heel to the tip of the longest digit including the claw), ear length (distance between the notch and the tip of the pinna), weight (body weight in grams).

\section{Cranial measurements}

Cranial measurements (in millimeters) were taken using a digital caliper to nearest $0.01 \mathrm{~mm}$. Measurements used to compare with those given by Thomas (1905) and with the original description (Thomas 1920b) are as follows: greatest length of the skull (distance from the most anterior part of the incisors to the most posterior point of the skull), condyloincisive length (distance between the most anterior point of the incisors and the posteriormost projection of the occipital condyles), zygomatic breadth (greatest distance between the outer margins of the zygomatic arches), length of nasals (from the anteriormost point of nasal bones to the posteriormost point, taken along the midline of the skull), least interorbital breadth (least distance dorsally between the orbits), bimeatal breadth (maximum width of the skull at the level of the external auditory meatus measured perpendicular to the sagittal plane of the skull), palatal length (from the posterior edge of the alveolus of the incisor to the anteriormost point of the posterior edge of the palate), length of the maxillary toothrow (distance from the anterior margin of the alveolus of the DP4 to the posterior margin of the alveolus of the last molar).

The following additional skull measurements were included, in order to add information that allows an enhanced description of the species: occipito-nasal length (distance between the anterior point of nasals and the posteriormost point of the occipital), breadth of the rostrum (maximum width of the rostrum), breadth of the braincase (distance across the braincase measured at a point in front of the auditory meatus and behind the zygomatic arches), length of diastema (distance between the anteriormost point of the edge of the alveolus of DP4 and the posteriormost point of the edge of the alveolus of the incisor of the same side), molar-molar (breadth across the last upper molar), length of the mandible (greatest length of the mandible from the anteriormost point of the alveolus of the incisors to the most posterior point of the angular process), length of the mandibular toothrow (alveolar length from the anterior edge of the alveolus of dp4 to the posterior edge of the alveolus of the last tooth) (Langguth and Abella 1970, Contreras and Contreras 1984).

\section{Molecular analyses}

Total DNA extractions were made with sodium dodecyl sulfate (SDS)/proteinase $\mathrm{K}$ digestion/ $\mathrm{NaCl}$ protein precipitation/alcohol precipitation of DNA (modified from the Miller et al. 1988) from the liver preserved in $95 \%$ ethyl-alcohol. The almost complete cytochrome $b$ gene was amplified using primers MVZ05 (Smith and Patton 1999) and TucoPro (Wlasiuk et al. 2003) Amplification was carried out in a total volume of $20 \mu \mathrm{l}$ containing the following final concentrations of each constituent: $10 \mu \mathrm{l}$ of DNA 
$(\approx 0.4 \mu \mathrm{g} / \mathrm{ml})$ used as a template, $1 \times$ Taq polymerase buffer, $240 \mu \mathrm{M}$ of each deoxyribonucleotide triphosphate (dNTP, QUIAGEN, cat number 201913), $240 \mathrm{nM}$ of each primer, 2 units of Taq polymerase (FERMENTAS EP0402) and $3 \mathrm{~mm}$ of $\mathrm{MgCl}_{2}$. Polymerase chain reaction (PCR) amplifications were performed in a PXE0.2 Thermal Cycler (Thermo Electron Corporation, Milford, MA, USA), by an initial denaturation of $3 \mathrm{~min}$ at $94^{\circ} \mathrm{C}$, followed by 35 cycles of $20 \mathrm{~s}$ of denaturation at $94^{\circ} \mathrm{C}, 20 \mathrm{~s}$ of annealing at $45^{\circ} \mathrm{C}$ and $20 \mathrm{~s}$ of extension at $72^{\circ} \mathrm{C}$ and a final extension of $5 \mathrm{~min}$ at $72^{\circ} \mathrm{C}$. In each reaction, the corresponding negative control was included. The amplified products were electrophoresed in $0.8 \%$ agarose gels (100 V, $20 \mathrm{~min}$ ), the DNA bands were visualized after GoodView staining under ultraviolet (UV) light and the expected size was determined in relation to a 100 bp DNA size standard (GIBCO BRL, New England Biolabs, catalogue number N3231S, Grand Island, NY, USA). PCR products were purified and automatic sequencing from both ends was done by Macrogen Inc. (http:// www.macrogen.com), under BigDyeTM terminator cycling conditions in an ABI 3730xl Sequencer. All sequences were deposited in GenBank. Sequences obtained were edited with Proseq (Filatov 2009) and the intron-exon structure and inspections of the lack of stop codons and in/dels that generate frameshift were checked.

These sequences were compared with other previously deposited in GenBank of the following species and accession numbers: Spalacopus cyanus (G. I. Molina 1782) (AF007061), Octodon degus (G. I. Molina 1782) (HM544134), O. degus (F007058), Ctenomys mendocinus Philippi 1869 (Tupungato) (F370695), C. mendocinus (Las Heras) (F007062), Ctenomys flamarioni Travi 1981 (F119107), Ctenomys australis Rusconi 1934 (F370697), Ctenomys porteousi Thomas 1916 (F370682), Ctenomys rionegrensis (F119103), Ctenomys opimus Wagner 1848 (F007042), Ctenomys scagliai J. R. Contreras 1999 (HM777494), Ctenomys occultus Thomas 1920 (HM777485), Ctenomys latro Thomas 1918 (HM777478), Ctenomys tucumanus Thomas 1900 (F370691), Ctenomys goodfellowi Thomas 1921 (F007050), Ctenomys boliviensis Waterhouse 1848 (F007038), Ctenomys. sp. "llathu” (F007048), Ctenomys frater Thomas 1902 (F007045), Ctenomys pundti Nehring 1900 (HM777491), Ctenomys talarum Thomas 1898 (HM777497), Ctenomys pearsoni Lessa and Langguth 1983 (HM777486), Ctenomys torquatus Lichteinstein 1830 (F119111), Ctenomys haigi Thomas 1919 (HM777476), Ctenomys magellanicus Bennett 1836 (HM777479), Ctenomys sericeus J. A. Allen 1903 (HM777496), Ctenomys. sociabilis Pearson and Christie 1985 (HM777495), Ctenomys steinbachi Thomas 1907 (F007044), Ctenomys. sp. "ita" (F007047), Ctenomys minutus Nehring 1887 (F007052),
Ctenomys leucodon Waterhouse 1848 (F007056), selecting at least two species per group defined by Parada et al. (2011). Among these sequences, Ctenomys fulvus, C. tucumanus, Ctenomys tuconax Thomas 1925 and C. occultus were included because the putative relationship regarding geographical proximity or phylogenetic affinity was previously suggested (Cabrera 1961). Based on the target sequence showed within the "mendocinus" group, all known species from this group were included (C. porteousi, C. australis, C. flamarioni, C. rionegrensis, and several sequences reported as $C$. mendocinus). Alignment (ClustalX) and phylogenetic reconstruction were performed in MEGA7 (Kumar et al. 2015), and different criteria were applied, such as maximum likelihood, maximum parsimony and Neighbor-Join with 1000 bootstrap seudoreplicates. Two species from the sister family Octodontidae (S. cyanus and O. degus) were used as the outgroup.

\section{Results}

\section{Comments on the collecting localities}

Between March and April 1920, Budin collected 10 specimens of Ctenomys famosus at three different points, during an expedition to the Famatina Chain, La Rioja Province, commissioned by Oldfield Thomas from the BMNH, London. One of the sites, "La Invernada", was also named as "Cerro Invernada" or "Cadena Invernada, 3800 m" by Budin, as written in his original field notes available at the PIDBA (Programa de Investigaciones de Biodiversidad Argentina) library. The other two places correspond to the points of different elevation indicated as "Potrerillo, $1600 \mathrm{~m}$ " and "Potrerillo, $2600 \mathrm{~m}$ ", it is important to mention that the town Potrerillo is placed at $1800 \mathrm{~m}$.

A field trip made to the area allowed us to make contributions to the systematic and distributional situation of this species, as well as to extend and improve the original description using the topotypic specimens. The location of the type locality and the original collecting points in the area were defined based on our observations in the site, together with the information provided by Thomas (1920b) and taken from the field notes of Budin.

Potrerillo is a small village with just a few houses located along a rural road of approximately $2 \mathrm{~km}$ in length. It is located approximately $1.7 \mathrm{~km}$ west of the current Provincial Route 11, on the eastern side of the Sierras de Famatina. It has been accurately located by us, and georeferenced at a point that corresponds to the main square 
of the village, $1820 \mathrm{~m}$ elevation. There we found active mounds and caves of Ctenomys and obtained the samples analyzed in this study. Also, three of the specimens from the type series were collected in the same site or near the surroundings, at $1600 \mathrm{~m}$.

The prospection of the place, added to the analysis of the bibliographical information and original notes of the collector, allowed us to interpret that the type specimen was collected about $3 \mathrm{~km}$ to the west, on the mountains, where the elevation noted in the article $(2600 \mathrm{~m})$ is to be found. This interpretation is based on the fact that we know well enough, based on the study of a long series of documents and field notes of Budin and his correspondence with Thomas that, when arrived to a place, he first established his campsite and then, from there, moved to different places to set the traps, preferably to the higher areas in the surroundings.

The geographical location assigned to "Potrerillo" in some previous publications (Bidau 2015) is erroneous, extralimital and positioned outside of La Rioja Province. As a result of this analysis, we propose an adjustment in defining the type locality as follows: "Potrerillo, $3 \mathrm{~km} \mathrm{~W}$, at the Eastern slopes of Sierras de Famatina, 2600 m”.

Our trip allowed us to collect two topotype specimens, as well as to analyze the area in order to interpret and define the original collecting sites and to complete and improve the original description of the species. In addition, we were able to obtain tissues from the specimens and to make a molecular analysis of the species.

Besides, we collected other specimens of this species in a new locality, which allows extending its geographical and elevation range, as well as to add morphological characters to the original description; this also proves that the species is not restricted to the type of locality, as it is generally proposed for most of the species of the genus. This allows us to assume that restrictions of many species to their type locality, imposed by several authors, are decisions based only on the absence of data and lack of field studies for the species.

Thomas (1920a) considered Ctenomys famosus and Ctenomys coludo as morphologically similar and geographically adjacent species. In effect, the type locality of $C$. coludo (La Puntilla, Tinogasta, Catamarca Province, $28^{\circ} 06^{\prime} 59.4^{\prime \prime} \mathrm{S} 67^{\circ} 29^{\prime} 59.6^{\prime \prime} \mathrm{W}, 1000 \mathrm{~m}$ ) is located at a very short distance from Potrerillo, about $37 \mathrm{~km}$ in a straight line, with an orographic and environmental continuity, which surely facilitates dispersion.

The main differences indicated by Thomas to separate the two species were the smaller tail length and the smaller bullae in Ctenomys famosus, but 1 year later (Thomas 1921) suggested that $C$. famosus could be considered as a subspecies of Ctenomys coludo. We also observed that the tail length is proportionally similar in both species in terms of percentage.

The original description of Ctenomys famosus is superficial, providing only a few external and cranial measurements, and basically offers comparisons with Ctenomys coludo, described in an earlier article by Thomas himself (1920a). The original description hardly refers to the similarity in color between both species, emphasizing some differences of measurements, in particular the length of the tail. For $C$. coludo, Thomas described the coloration as "General color above pale..., paler than in most species...", and for C. famosus he simply says "Color quite as in that animal...". He also describes that the size of famosus is "about as in coludo, or perhaps a little smaller, but differences of age make exact size-comparison difficult". Later, Thomas (1921) proposed to treat $C$. famosus as a subspecies of $C$. coludo.

With respect to the proposed main diagnostic difference between the two species, the length of the tail, we analyzed that although the tail length is different in each species ( $97 \mathrm{~mm}$ in coludo/74 $\mathrm{mm}$ in famosus), its relation to head and body size (302 $\mathrm{mm}$ in coludo/234 $\mathrm{mm}$ in famosus) reveals a similar proportion in terms of percentage for the two species (32.1\% in coludo/31\% in famosus).

Performing genetic and morphological analysis of Ctenomys coludo will surely help in defining the systematic status of each species. For now we can only keep Ctenomys famosus as a valid species, extending its range of distribution and elevation. As the known distribution of $C$. coludo is very close from Potrerillo, it is probable that the two forms are in fact one species, with a distribution that is wider than suggested so far.

\section{Amended description of Ctenomys famosus, Thomas 1920}

It is based on the topotype specimen CML11029. The pelage is dense, soft and bright; the length of the dorsal hairs is variable, about $20 \mathrm{~mm}$ long over the back and $10 \mathrm{~mm}$ on the head. The general coloration is light brown with a copper tone, the mid-dorsal stripe is darker especially on the head where a mix of black hairs can be observed from the nose to the middle of the ears (Figure 3); the cheeks are lighter; the dorsal hairs are dark slate gray basally (about $8 \mathrm{~mm}$ ), followed by light ochraceous brown bands (about $9 \mathrm{~mm}$ ) and black terminal tips (about $1 \mathrm{~mm}$ ). Posteriorly, at the level of the rump, long and white hairs (about $25 \mathrm{~mm}$ ) that protrude from the fur can be observed. The lateral coloration, behind the forefoot and the belly, is notably lighter, pale cream almost whitish. Bases of hairs are dark slate 


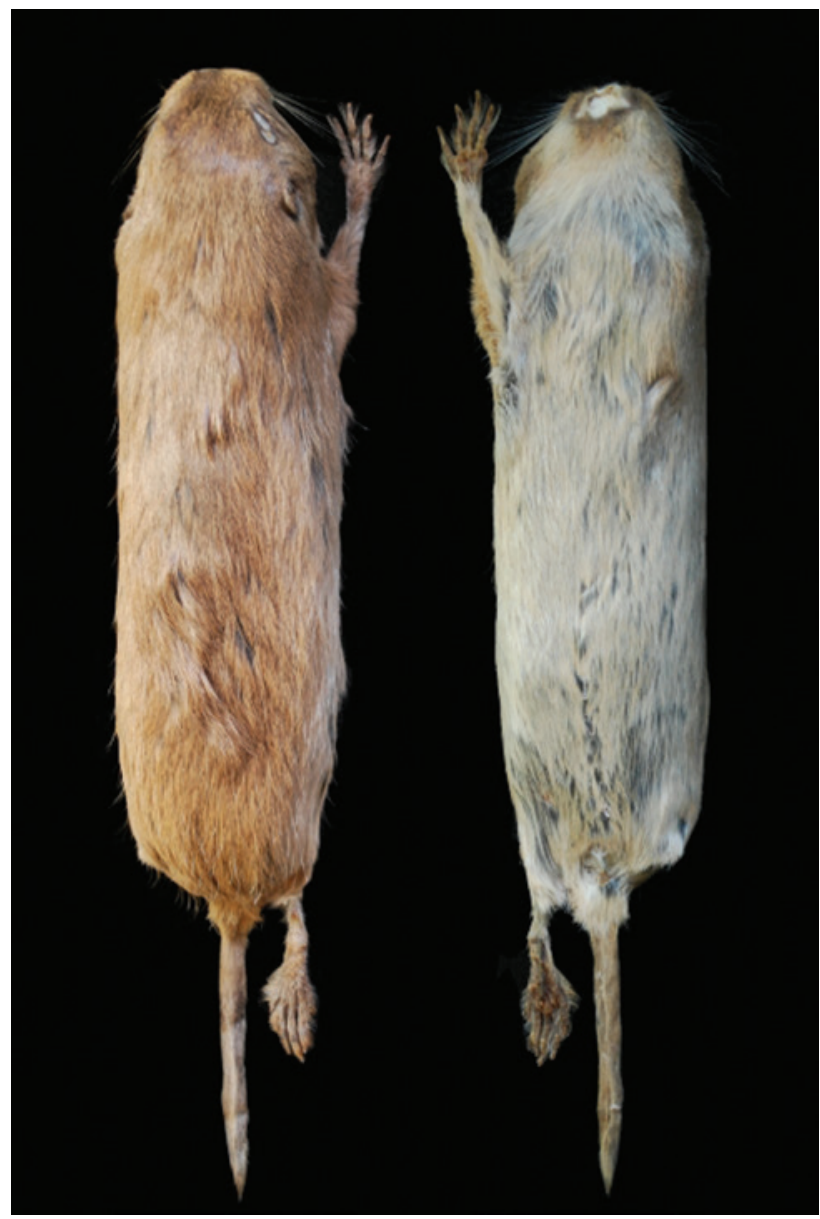

Figure 3: Dorsal and ventral views of the skin of the topotype of Ctenomys famosus (CML 11028).

gray (about $8 \mathrm{~mm}$ on the sides and $5 \mathrm{~mm}$ on the belly) with pale cream tips (about $10 \mathrm{~mm}$ on the sides and $9 \mathrm{~mm}$ on the belly). The ears are small, rounded and without a notch, drab colored and sparsely covered by short brown hairs; at the base of the ears there is a small tuft of pale cream hairs with black tips. The muzzle is dark brown; mystacial vibrissae are a mixture of black and white hairs that surpasses the eyes, with some reaching to the posterior edge of the ears; superciliary vibrissae are black, and at least four of them can be observed on the anterior border of the eye; those located on the upper side are longer reaching the ears when laid back; no genal or interramal vibrissae are present. Bundles of stiff white hairs can be seen on the upper and lower borders of the lips.

The tail is robust but shorter than the head and the body (about 34\%); pale cream both dorsally and ventrally. The base of the tail is very hairy but less dense toward the tip and to the sides, such that the scales can be clearly seen; ventrally it is hairier and ends in a small tuft of hairs (Figure 3).
The feet are large and robust; the forefeet have the same color as the dorsum both dorsally and ventrally; metacarpals are covered with paler hairs, and digits and nails are covered with long and white hairs; the pads are naked. The pollex is well developed and has a short open nail; the digits 2-4 are long and have basally closed claws. The hindfeet are dorsal and laterally covered with pale cream hairs which are less dense than in the forefeet; these hairs cover up to metacarpals where they are replaced with "cteniform" bristles over each nail and digits; the presence of a comb-like bristle of long hairs (about $5 \mathrm{~mm}$ ) on the middle edge of the fifth digit is notable; the hallux is well developed with a long and open claw as well as in the other digits.

The skull is robust (see measurements in Table 1); the rostrum is broad, short and strong; the premaxillary bones are visible from the dorsal view; nasals are short, slightly broadened at the tip, located behind the incisors and posteriorly at about the same level of premaxillary bones (Figure 4); in the lateral view, they are slightly convex. The lacrimal is small and not expanded. The interorbital breadth is subequal to the breadth of the rostrum. The postorbital process of the frontal is flat, and a small salience can be observed.

An interfrontal fontanelle is present; the parietals have no crests; the fronto-parietal suture is slightly rounded, and the squamosal is dorsally extended which is clearly evident in the dorsal view. The interparietal is small, triangular and only visible from the dorsal view. In the dorsal view, at both sides of the interpariental, two islets of the epitympanic sinus which are irregularly rounded are observed, and contiguous to these the well-developed hamular processes of the squamosal are present; the hamular separates the islet from the external auditory meatus; the subsquamosal foramen is dorsal and much reduced and the postglenoid foramen is ventral and drop-shaped with the sharpest end oriented backward. A portion of the occipital is visible in the dorsal view; dorsal edge of the foramen magnum with two poorly developed projections is observed; the mastoid apophysis is evident behind the external auditory meatus with the stylomastoid foramen present; the paraoccipital processes are well developed, wide, flattened and completely adpressed ventrally to the bulla.

In the lateral view, the interorbital bar is slender and slightly tilted antero-posteriorly. The zygomatic arches are wide, curved and little expanded; the paraorbital apophysis, formed only by the jugal, is projected inwards as a tip; the lower end of the jugal process is small but evident and projected posteriorly to the level of the paraorbital apophysis; the tip of the jugal process is rounded and extended beyond the squamosal; the ventral zygomatic root is at 
Table 1: Mean, ranges and specimen numbers (in brackets) of body and cranial measurements of the holotype, topotypes, series of specimens collected in this study, series of Ctenomys famosus at BMNH and topotype specimens of Ctenomys rionegrensis (see details in the Materials and methods section).

\begin{tabular}{|c|c|c|c|c|c|}
\hline & \multicolumn{4}{|c|}{ Ctenomys famosus } & \multirow{2}{*}{$\frac{\text { Ctenomys rionegrensis }}{\text { Topotypes }}$} \\
\hline & Holotype BMNH 20.8.4.54 & Topotype CML 11028 & This study & Series at BMNH & \\
\hline Total length & 234 & 245 & $\begin{array}{r}240.5 \\
233-249 \\
(4)\end{array}$ & $\begin{array}{r}208.9 \\
159-237 \\
(6)\end{array}$ & $\begin{array}{r}252.7 \\
242-263 \\
(3)\end{array}$ \\
\hline Head and body & 169 & 164 & $\begin{array}{r}156.5 \\
144-164 \\
(4)\end{array}$ & $\begin{array}{r}145.0 \\
107-164 \\
(6)\end{array}$ & $\begin{array}{r}178.0 \\
171-190 \\
(3)\end{array}$ \\
\hline Tail length & 74 & 81 & $\begin{array}{r}84.0 \\
81-89 \\
(4)\end{array}$ & $\begin{array}{r}65.1 \\
52-73 \\
(6)\end{array}$ & $\begin{array}{r}74.7 \\
71-80 \\
(3)\end{array}$ \\
\hline Hindfoot length & 31.5 & 35 & $\begin{array}{r}35.0 \\
35.0 \\
(4)\end{array}$ & $\begin{array}{r}28.9 \\
23.5-31.7 \\
(6)\end{array}$ & $\begin{array}{r}35.0 \\
33-37 \\
(3)\end{array}$ \\
\hline Ear length & 6.7 & 6 & $\begin{array}{r}6.0 \\
6.0 \\
(4)\end{array}$ & & $\begin{array}{r}8.3 \\
8-9 \\
(3)\end{array}$ \\
\hline Weight & & 130 & $\begin{array}{r}155 \\
135-185 \\
(4)\end{array}$ & & $\begin{array}{r}152 \\
148-156 \\
(3)\end{array}$ \\
\hline Greatest length of skull & 41 & 39.7 & $\begin{array}{r}41.0 \\
39.7-43.2 \\
(3)\end{array}$ & & $\begin{array}{r}41.2 \\
40.0-42.4 \\
(2)\end{array}$ \\
\hline Condylo-incisive length & 40.2 & 39.7 & $\begin{array}{r}40.2 \\
39.0-41.7 \\
(3)\end{array}$ & $\begin{array}{r}37.71 \\
33.01-39.8 \\
(5)\end{array}$ & $\begin{array}{r}39.6 \\
38.8-40.4 \\
(2)\end{array}$ \\
\hline Occipital-nasal length & 40.4 & 38.9 & $\begin{array}{r}39.3 \\
38.9-39.8 \\
(2)\end{array}$ & $\begin{array}{r}38.20 \\
35.11-40.6 \\
(5)\end{array}$ & $\begin{array}{r}38.2 \\
37.4-39.0 \\
(2)\end{array}$ \\
\hline Breadth of braincase & 15.7 & 15.9 & $\begin{array}{r}16.7 \\
15.9-17.5 \\
(3)\end{array}$ & $\begin{array}{r}16.1 \\
15.1-17.4 \\
(5)\end{array}$ & $\begin{array}{r}16.2 \\
16.0-16.3 \\
(2)\end{array}$ \\
\hline Least interorbital breadth & 8.3 & 8.0 & $\begin{array}{r}8.5 \\
8.0-9.0 \\
(3)\end{array}$ & & $\begin{array}{r}9.4 \\
9.1-9.7 \\
(2)\end{array}$ \\
\hline Zygomatic breadth & 24.3 & 22.5 & $\begin{array}{r}24.0 \\
22.5-24.8 \\
(3)\end{array}$ & $\begin{array}{r}23.4 \\
21.2-25.8 \\
(5)\end{array}$ & $\begin{array}{r}18.6 \\
18.2-19.0 \\
(2)\end{array}$ \\
\hline Bimeatal breadth & 26.7 & 25.6 & $\begin{array}{r}26.7 \\
25.6-27.5 \\
(3)\end{array}$ & & $\begin{array}{r}22.54 \\
22.1-22.9 \\
(2)\end{array}$ \\
\hline Breadth of rostrum & 8.3 & 7.9 & $\begin{array}{r}8.9 \\
7.9-9.6 \\
(3)\end{array}$ & $\begin{array}{r}8.5 \\
7.5-9.3 \\
(5)\end{array}$ & $\begin{array}{r}9.17 \\
8.8-9.5 \\
(2)\end{array}$ \\
\hline Length of diastema & 10.0 & 10.1 & $\begin{array}{r}10.6 \\
10.1-11.7 \\
(3)\end{array}$ & $\begin{array}{r}9.3 \\
7.9-10 \\
(5)\end{array}$ & $\begin{array}{r}10.1 \\
9.5-10.8 \\
(2)\end{array}$ \\
\hline Length of maxillary toothrow & 9.5 & 8.0 & $\begin{array}{r}8.3 \\
8.0-8.7 \\
(3)\end{array}$ & $\begin{array}{r}8.7 \\
8.0-9.0 \\
(5)\end{array}$ & $\begin{array}{r}9.9 \\
9.2-10.6 \\
(2)\end{array}$ \\
\hline
\end{tabular}


Table 1 (continued)

\begin{tabular}{|c|c|c|c|c|c|}
\hline & \multicolumn{4}{|c|}{ Ctenomys famosus } & \multirow{2}{*}{$\frac{\text { Ctenomys rionegrensis }}{\text { Topotypes }}$} \\
\hline & Holotype BMNH 20.8.4.54 & Topotype CML 11028 & This study & Series at BMNH & \\
\hline \multirow[t]{3}{*}{ Palatal length } & 17.5 & 17.2 & 17.42 & 16.3 & 19.6 \\
\hline & & & $16.5-18.5$ & $14.5-17.6$ & $18.9-20.4$ \\
\hline & & & (3) & (5) & (2) \\
\hline \multirow[t]{3}{*}{ Length of nasals } & 14.0 & 13.8 & 14.2 & 14.1 & 13.5 \\
\hline & & & $13.0-15.7$ & $12.9-15.9$ & $13.1-13.8$ \\
\hline & & & (3) & (5) & (2) \\
\hline \multirow[t]{3}{*}{ Length of mandible } & & 30.0 & 30.7 & & 32.1 \\
\hline & & & $30.0-31.4$ & & $31.1-33.1$ \\
\hline & & & (3) & & (2) \\
\hline \multirow[t]{3}{*}{ Length of mandibular toothrow } & & 8.6 & 8.9 & & 10.0 \\
\hline & & & $8.6-9.2$ & & $9.6-10.0$ \\
\hline & & & (3) & & $(2)$ \\
\hline \multirow[t]{3}{*}{ Molar-molar } & 7.3 & 8.0 & 8.1 & 7.1 & 8.13 \\
\hline & & & $7.8-8.5$ & $6.4-7.6$ & $7.7-8.5$ \\
\hline & & & (3) & (5) & (2) \\
\hline
\end{tabular}

the level of DP4. The jugal fossa is slightly marked and the maxillar-jugal suture is sub rectangular. The gnathic process is little developed; the roots of the incisors are

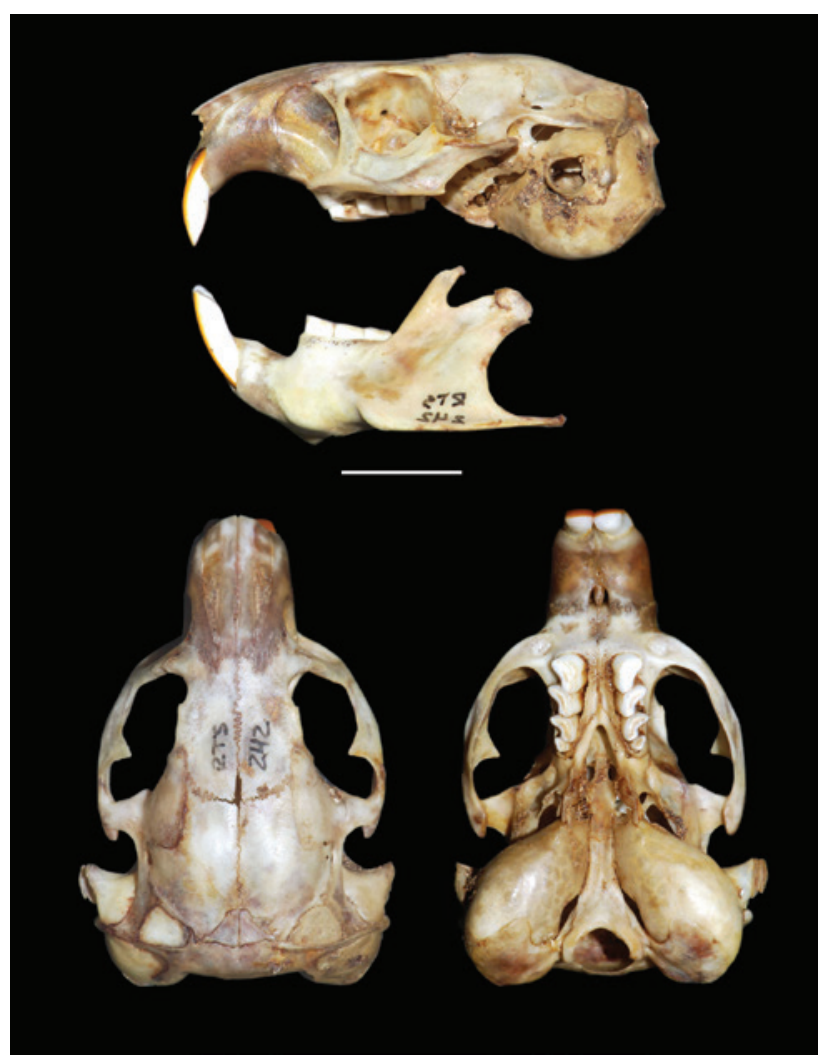

Figure 4: Lateral view of the skull and the mandible, and dorsal and ventral views of the skull of the topotype of Ctenomys famosus (CML 11028); scale bar $=5 \mathrm{~mm}$. observed at the level of the zygomatic root. The infraorbital canal is flat, without groove or flange.

The strong hypsodonty of the molars make the sphenopalatine foramen to be reduced to a vertical slit located in front of the alveolus of M1 and behind the root of the incisors, and completely surrounded by the maxillary bone. Dorsally, and anterior to the root of the M2 on the frontal, the etmoidal foramen can be observed; above and somewhat posterior to this foramen, below the orbital process, the sphenofrontal foramen is present. The palatine is placed between the maxillary and the alisphenoid. The masticatory and buccinator foramina, separated by a septum, can be observed on the aliesphenoid; the medial lacerate foramen and the oval foramen are united to form a great cavity; also, the alisphenoid bridge has a projection oriented toward the tympanic bulla. The bullae are medium sized compared with the other species of the genus; are pyriform, antero-posteriorly oblique with the anterior tip narrower, and the external auditory meatus is long, protruding and antero-ventrally oriented. When the skull is seen from above, the bullae are expanded beyond the occipital bone, and the auditory meatus is laterally expanded.

In the ventral view, a small interpremaxillary foramen is present; the incisive foramina are small and separated by a septum to the level of the premaxillary bones. The palate is shallow, short and extended to the middle of the M2; behind M3 the posteropalatal pits, between maxillary and palatine, are observed. The mesopterigoid fossa is deep and inverted V-shaped, and pterygoids are in contact with the anterior end of the bullae. The glenoid fossa is posteriorly continued through a narrow postglenoid fossa 
formed by the posterior root of the squamosal apophysis. The sphenopalatine pits are evident. The limit between presphenoid and basisphenoid is at the level between M2 and M3, and the limit between basisphenoid and basioccipital is behind the anterior end of the bullae. Between the basiocciptal and the bullae the jugular foramen is placed, and behind this, at both sides of the condyles, the hypoglossal foramen is observed.

The mandible is strongly hystricognath, the angular process is sharp and extended much posteriorly behind the condylar process. The latter is short and narrow and the postcondylar process is clearly evident and laterally expanded. The lunar notch is C-shaped and moderately deep. The coronoid process is triangular, relatively large and backward oriented, with a sigmoid notch closed approximately at a $45^{\circ}$ angle. Both condylar and coronoid processes are high in relation with the toothrow. The symphysis extends to the posterior edge of the dp4. The base of the mandibular branch has projections to both sides extended inward forming a base in the ventral view. The ventromedial process is marked and, on the longitudinal plane, the incisive branch forms an angle of $45^{\circ}$. The masseteric fossa has a marked dorsal subdivision.

The dental formula is $1 / 1,0 / 0,1 / 1,3 / 3$. The upper and lower incisors are strong and orange; the upper incisors are slightly procumbent and surpassed the nasals. The upper toothrows are slightly divergent and the teeth are leaning toward the labial side, while the lower toothrows are more parallel and the teeth are leaning toward the lingual side. The DP4 is the largest in the series and the other molars gradually decrease in size backward, the M3 being much smaller and oval; the dp4 is and the first two lower molars are similar in size, the dp4 narrower and the $\mathrm{m} 3$ is rounded and smaller even than M3. The molariforms are kidney-shaped, with the major axis antero-labially positioned; in the upper molariforms the greater lobule is labially oriented with an external concavity and a small groove in the lingual side, the last one is absent in M3. The lower molariforms have a lingual concavity.

No sexual dimorphism was observed in external and cranial measurements of the specimens analyzed. All collected specimens agree with the above offered description; however, in specimens from San Blas, (CML 11030, 11031) and Potrerillo (CML 11028) the dorsal coloration is slightly a bit darker compared with the topotype. In specimens from San Blas, the plumbleous bases of ventral hairs are more notable, and the tip of the tail is darker. In all specimens the tail is shorter (33\%-38\%) than the length of the head and the body. The skulls seem to be identical in all specimens with just some minor individual variations, for example, the interfrontal fontanella is absent in specimens CML 11031 and 11028; in CML 11030 the lower end of the jugal process is small but less evident and blunter and projected posteriorly in front of the paraorbital apophysis, and the masticatory and buccinator foramina are not separated by a septum.

On the other hand, body measurements of Ctenomys famosus and Ctenomys rionegrensis have similar ranges. However, the detailed analyses of the skull in both species reflect significant differences supporting the molecular study. The skull of $C$. rionegrensis is less robust than that of C. famosus, the rostrum is wider, the postorbital processes are located more posteriorly with a marked constriction behind them and the occipital bone and the bullae are not projected so they cannot be observed from the dorsal view. In the mandible, the angular process in C. rionegrensis is shorter and thicker than in C. famosus.

\section{Molecular analysis}

The sequences were deposited in GenBank with accession numbers from MH048839 to MH048841. The topologies of the genus Ctenomys obtained with different criteria are in agreement with those found in previous studies (D'Elía et al. 1998, Castillo et al. 2005, Parada et al. 2011) and are not discussed here (Figure 5).

The two samples from Potrerillo are the same haplotype, while the samples from San Blas are two different haplotypes. All these haplotypes are closely related and form a monophyletic clade clearly included within the "mendocinus group", which is recovered by different methods tried with high bootstrap values (nearly 100). The observed divergence among haplotypes from San Blas and the one observed for Ctenomys famosus ranged from five to 10 nucleotide changes, corresponding to a p-distance (0.5-1.2\%) comparable to intraspecific distances (e.g.: Parada et al. 2011, 2012) within the "mendocinus group". We conclude that these two populations, "Potrerillo" and "San Bla" belong to the same species, C. famosus.

The closest species to Ctenomys famosus among the known species of the mendocinus group would be Ctenomys rionegrensis or a misclassified sequence of Ctenomys mendocinus that came from Tupungato, although low bootstrap values, and discrepancies between phylogenetic criteria, do not allow to be conclusive. These results strongly reject the idea proposed by Cabrera (1961) with respect to considering $C$. famosus as a subspecies of Ctenomys fulvus, a species belonging to a distant group of Ctenomys. The other species that could be related to $C$. famous due to geographical or environmental affinities (i.e.: Ctenomys coludo, Ctenomys fochi and Ctenomys knighti, from Catamarca, and Ctenomys johannis, Ctenomys tulduco from 


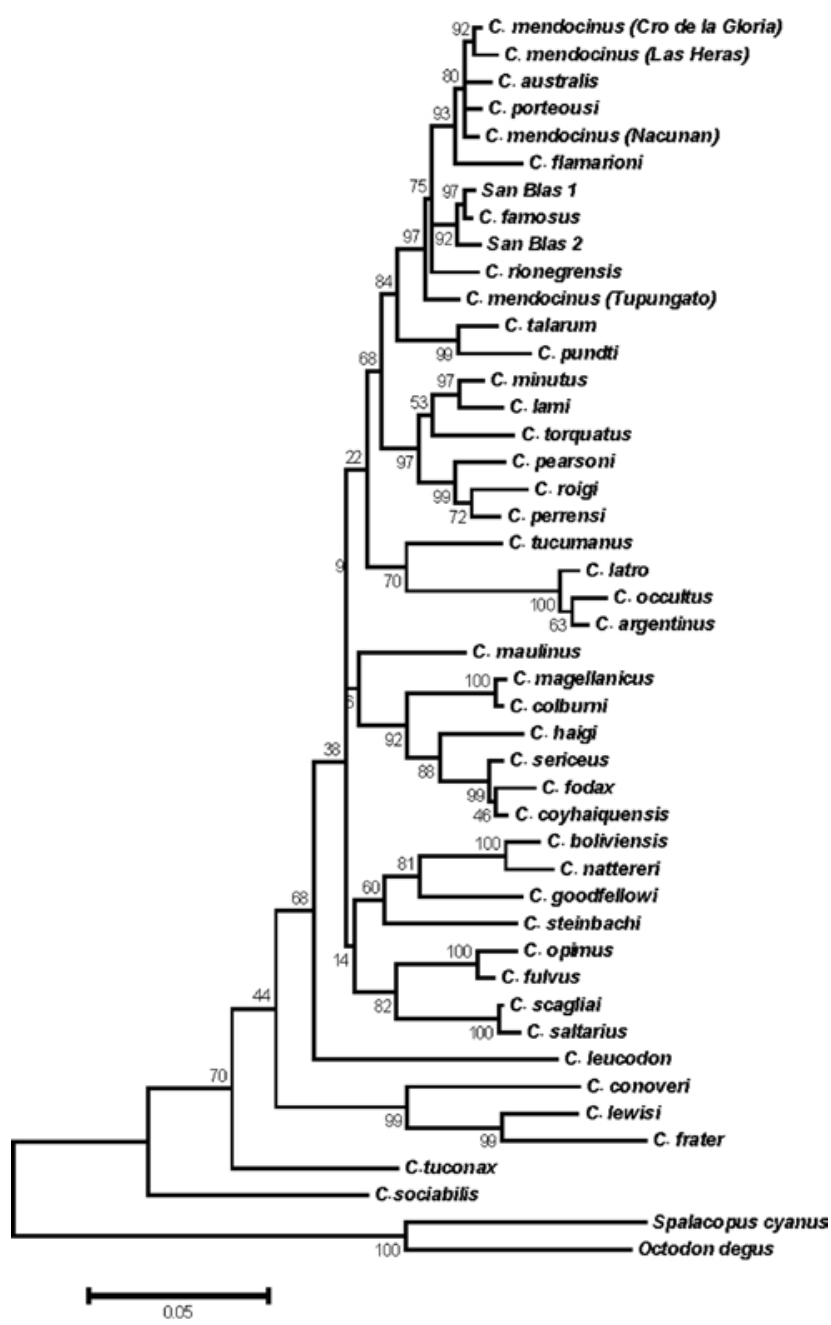

Figure 5: Molecular phylogenetic analysis of cytochrome $b$ gene sequences.

The evolutionary history was inferred by using the maximum likelihood method based on the general time reversible model. Numbers over each node are bootstrap values (1000 pseudoreplicates).

San Juan) could not be assessed due to the lack of information and available tissue samples.

Although Ctenomys famosus is molecularly close to Ctenomys rionegrensis, there is no external morphological similarity between them because $C$. rionegrensis is highly variable in coloration (D’Elía et al. 1998, Wlasiuk et al. 2003); external body measurements are sexually variable in $C$. rionegrensis, with males being larger than females.

\section{Discussion}

Within the genus Ctenomys a large number of species have been described, but for most of them there is scarce information available. Practically nothing is known about the natural history of most species, or about their actual limits of distribution, nor their phylogenetic relationships.

This is especially true for species distributed in northwestern Argentina, suggesting the need to implement studies linking morphology, morphometry and molecular analyses, which will help to obtain a more general and complete overview of the biology of the species of the region. In particular, we wish to emphasize the need to study the species described previously, on which only data of the type specimens are known, with significant gaps of information, descriptive, morphological and distributional, and also an almost total lack of knowledge at the molecular level.

In this sense, this study is a beginning to provide modern information, especially detailed descriptions of the species, molecular, additional environmental data and greater precisions about the site of the type localities, based first on the collection of topotypes. For example, one of the less known species of the genus, Ctenomys famosus, was only known from the two localities indicated in the type description by Thomas (1920b), but a more extensive collecting effort has allowed us to find this species in a third locality, as well as complete and improve the original extremely brief description of the skull and skin. At the molecular level, we also characterize the cytochrome $b$ of C. famosus, and our analysis places this species as a member of the "mendocinus" group of Ctenomys.

This information can serve as a basis for future research in order to favor clarifying the evolutionary panorama of the group at the regional level, as well as for completing the existing relationships within the complex of the Argentine species of the genus.

Acknowledgments: This study has been possible thanks to the support of the institutions CONICET(Consejo Nacional de Investigaciones Científicas y Técnicas), Facultad de Ciencias Naturales e Instituto Miguel Lillo and Colección Mamíferos Lillo (CML) and Universidad Nacional de Tucumán, Argentina. The Programa de Investigaciones de Biodiversidad en Argentina (PIDBA) also logistically and academically supported this research. We are grateful for the field assistance by Carina Colque and María Eugenia Montani.

\section{References}

Baker, R.J. and S.L. Williams. 1972. A live trap for pocket gophers. J. Wildl. Manage. 36: 1320-1322.

Bidau, C.J. 2015. Familia Ctenomyidae. In: (J.L. Patton, U.F.J. Pardiñas and G. D’Elía, eds.) Mammals of South America, Volume 2 - Rodents. The University of Chicago Press, Chicago, IL. pp. 818-877. 
Burkart, R., N. Barbaro, R.O. Sanchez and D.A. Gómez. 1999. Ecoregiones de la Argentina. Administración de Parques Nacionales, PRODIA, pp. 43.

Cabrera, A. 1961. Catálogo de los Mamíferos de América del Sur. Revista del Museo Argentino de Ciencias Naturales "Bernardino Rivadavia” e Instituto Nacional de Investigación de las Ciencias Naturales. Ciencias Zoológicas 4: 309-732.

Castillo, A.H., M.N. Cortinas and E.P. Lessa. 2005. Rapid diversification of South American tuco-tucos (Ctenomys; Rodentia, (tenomyidae): contrasting mitochondrial and nuclear intron sequences. J. Mammal. 86: 170-179.

Contreras, J.R. and ANCh de Contreras. 1984. Diagnosis preliminar de una nueva especie de "Anguyá- tutú" (género Ctenomys) para la provincia de Corrientes, Argentina (Mammalia, Rodentia). Historia Natural 4: 131-132.

Díaz, M.M., D.A. Flores and R.M. Barquez. 1998. Instrucciones para la preparación y conservación de mamíferos. Publicaciones especiales No. 1. PIDBA, Universidad Nacional de Tucumán, Tucumán, Argentina. pp. 44.

D’Elía, G.A., E.P. Lessa and J.A. Cook. 1998. Geographic structure, gene flow, and maintenance of melanism in Ctenomys rionegrensis (Rodentia: Octontidae). Zeitschrift für Säugetierkunde 63: 285-296.

Filatov, D.A. 2009. Processing and population genetic analysis of multigenic datasets with ProSeq3 software. Bioinformatics 25: 3189-3190.

Kumar, S., G. Stecher and K. Tamura. 2015. MEGA7: Molecular Evolutionary Genetics Analysis version 7.0. for bigger datasets. Mol. Biol. Evol. 33: 1870-1874.

Langguth, A. and A. Abella. 1970. Las especies uruguayas del género Ctenomys (Rodentia-Octodontidae). Comunicaciones Zoológicas del Museo de Historia Natural de Montevideo, 129: $1-28$.

Lessa, E.P. and J.A. Cook. 1998. The molecular phylogenetics of tuco-tucos (genus Ctenomys, Rodentia: Octodontidae) suggests an early burst of speciation. Mol. Phylogenet. Evol. 9: 88-99.

Mascheretti, S., P.M. Mirol, M.D. Giménez, C.J. Bidau, J.R. Contreras and J.B. Searle. 2000. Phylogenetics of the speciose and chromosomally variable rodent genus Ctenomys (Ctenomyidae, Octodontoidea), based on mitochondrial cytochrome b sequences. Biol. J. Linnean Soc. 70: 361-376.

Massarini, A.I., M.A. Barros, M.O. Ortells and O.A. Reig. 1991. Chromosomal polymorphism and small karyotype differentiation in a group of Ctenomys species from Central Argentina (Rodentia: Octodontidae). Genetica 83: 131-144.
Miller, S.A., D.D. Dikes and H.H. Polesky. 1988. A simple salting procedure for extracting DNA from human nucleated cells. Nucleic Acids Res. 16: 215.

Parada, A., G.A. D’Elía, C.J. Bidau and E.P. Lessa. 2011. Species groups and the evolutionary diversification of tuco-tucos, genus Ctenomys (Rodentia: Ctenomyidae). J. Mammal. 92: 671-682.

Parada, A., A. Ojeda, S. Tabeni and G.A. D’Elía. 2012. The population of Ctenomys from the Ñacuñán Biosphere Reserve (Mendoza, Argentina) belongs to Ctenomys mendocinus Philippi, 1869 (Rodentia: Ctenomyidae): molecular and karyotypic evidence. Zootaxa 3402: 61-68.

Reig, O.A. and C.A. Quintana. 1992. Fossil ctenomyine rodents of the genus Eucelophorus (Caviomorpha: Octodontidae) from the Pliocene and Early Pleistocene of Argentina. Ameghiniana 29: 363-380.

Rundel, P.W., P.E. Villagra, M.O. Dillon, S. Roig-Juñent and G. Debandi. 2007. Arid and semi arid ecosystems. In: (T.T. Veblen, K.R. Young and A.R. Orme, eds.) The physical geography of South America. Oxford University Press, New York. pp. 158-199.

Slamovits, C.H., J.A. Cook, E.P. Lessa and M.S. Rossi. 2001. Recurrent amplifications and deletions of satellite DNA accompanied chromosomal diversification in South American tuco-tucos (genus Ctenomys, Rodentia: Octodontidae): a phylogenetic approach. Mol. Biol. Evol. 18: 1708-1719.

Smith, M.F. and J.L. Patton. 1999. Phylogenetic relationships and the radiation of sigmodontine rodents in South America: evidence from cytochrome-b. J. Mammal. Evol. 6: 89-8128.

Thomas, 0.1905. Suggestions for the nomenclature of the cranial length measurements and of the cheek-teeth of mammals. Proc. Biol. Soc. Washington 18: 191-196.

Thomas, 0.1920a. On mammals from near Tinogasta, Catamarca, collected by Sr. Budin. Ann. Mag. Nat. Hist. 6: 116-120.

Thomas, 0.1920b. On small mammals from the Famatina Chain, North-western Rioja. Ann. Mag. Nat. Hist. 6: 417-422.

Thomas, 0. 1921. The tuco-tuco of San Juan. Ann. Mag. Nat. Hist. 6: 523-524.

Verzi, D.H. 2002. Patrones de evolución morfológica en Ctenomyinae (Rodentia, Octodontidae). Mastozoología Neotropical 9: 309-328.

Verzi, D.H. and A.I. Olivares. 2006. Craniomandibular joint in South American burrowing rodents (Ctenomyidae): adaptations and constraints related to a specialized mandibular position digging. J. Zool. 270: 488-501.

Wlasiuk, G., J.C. Garza and E.P. Lessa. 2003. Genetic and geographic differentiation in the Rio Negro tuco-tuco (Ctenomys rionegrensis): inferring the roles of migration and drift from multiple genetic markers. Evolution 57: 913-926. 